\title{
Pengaruh Konsentrasi dan Interval Penyiraman Air Kelapa terhadap Pertumbuhan dan Hasil Jamur Tiram Putih (Pleurotus ostreatus)
}

\author{
The Effect of Concentrations And The Coconut Watering Intervals on The Growth And Yields of White Oyster \\ Mushroom (Pleurotus ostreatus)
}

\author{
Nur Azizah $^{1}$, Nurhayati ${ }^{2}$, Rita Hayati ${ }^{2}$ \\ ${ }^{1}$ Mahasiswa Program Studi Agroteknologi, Fakultas Pertanian, Universitas Syiah Kuala \\ ${ }^{2}$ Staf Dosen Program Studi Agroteknologi, Fakultas Pertanian, Universitas Syiah Kuala
}

\begin{abstract}
Abstrak. Penelitian ini bertujuan untuk mengetahui pengaruh konsentrasi dan interval penyiraman air kelapa yang tepat serta mengetahui pengaruh interaksi antara konsentrasi air kelapa dan interval penyiraman air kelapa terhadap pertumbuhan dan hasil jamur tiram putih. Penelitan ini dilaksanakan di UPTD Balai Benih Hortikultura Saree Kabupaten Aceh Besar, pada bulan mei sampai juli 2018. Unit-unit penelitian disusun berdasarkan rancangan acak lengkap pola faktorial $4 \times 4$ dengan 3 ulangan dan dilanjutkan dengan uji beda nyata jujur taraf 5\% pada hasil uji $\mathrm{F}$ yang signifikan. Faktor pertama adalah pemberian konsentrasi air kelapa dengan konsentrasi: $0,25,50$ dan $75 \%$ dan faktor kedua adalah interval penyiraman air kelapa dengan interval: 1 hari sekali, 2 hari sekali, 3 hari sekali dan 4 hari sekali. Hasil penelitian menunjukkan bahwa perlakuan konsentrasi air kelapa berpengaruh sangat nyata terhadap parameter pertumbuhan awal miselium,diameter tudung jamur, jumlah tubuh buah, bobot segar tubuh buah per baglog dan bobot segar tubuh buah selama 3 kali panen, berpengaruh tidak nyata pada parameter laju pertumbuhan miselium dan panjang tangkai tudung buah. Konsentrasi terbaik terdapat pada perlakuan konsentrasi air kelapa 50\%. Interval penyiraman air kelapa berpengaruh sangat nyata pada parameter diameter tudung jamur, jumlah tubuh buah, bobot segar tubuh buah per baglog dan bobot segar tubuh buah selama 3 kali panen, berpengaruh nyata pada parameter panjang tangkai tudung buah dan berpengaruh tidak nyata pada parameter pertumbuhan awal miselium, laju pertumbuhan miselium dan jumlah tubuh buah. Interval penyiraman terbaik terdapat pada perlakuan interval penyiraman 2 hari sekali. Interaksi antara konsentrasi air kelapa dan interval penyiraman berpengaruh nyata terhadap diameter tudung buah. Kombinasi perlakuan terbaik terdapat pada konsentrasi air kelapa 50\% dan interval penyiraman 2 kali sehari.
\end{abstract}

Kata kunci : Konsentrasi, interval penyiraman, air kelapa, jamur tiram putih

Abstract. This research aims to determine the effect of concentrations and the intervals of watering of coconut water on the growth and yields of white oyster mushroom. This research was carried out at Saree UPTD Horticulture Seed Centre, Aceh Besar regency from Mei to July 2018. The research units were compiled based on a Completely Randomized Design-factorial $4 \times 4$ with 3 replications and continued with Honestly Significance Difference test (Turkey test) level of $5 \%$ on a significant $F$ test result. The first factors were the concentrations of coconut water : $0,25,50$, and $75 \%$. The second factors were the interval of watering: once a day, twice a day, three times a day and four times a day. The result of the research showed that the concentrations of coconut water treatment were highly significant on initial growth of mycelium, mushroom hood diameter, the number of mushrooms, mushroom fresh weight per baglog and mushroom fresh weight for 3 times harvest and it was not significant on the rate of mycelium growth and long fruit hood stalk. 50\% concentration of coconut water treatment gives the best result on the growth and yield. The intervals of watering of coconut water was highly significant on mushroom hood diameter, the number of mushrooms, mushroom fresh weight per baglog and mushroom fresh weight for 3 times harvest and they significant on long fruit hood stalk and not significant on initial growth of mycelium, the rate of mycelium growth and the number of mushrooms. The interval of watering twice a day treatment shows the best result on the growth and yields of white oyster mushroom. The interaction of concentrations of coconut water and the interval of watering was significant on mushroom hood diameter. 50\% concentration of coconut water and the interval of watering twice a day shows the best result on growth and yields of white oyster mushroom.

Keyword: Concentrations, intervals of watering, coconut water, white oyster mushroom

\subsection{Latar Belakang}

\section{PENDAHULUAN}

Jamur tiram (Pleurotus ostreatus) merupakan jamur pangan yang memiliki tudung mirip dengan cangkang tiram dengan bagian tengahnya yang agak lekuk dan berwarna putih hingga krem. Jamur tiram putih memiliki bidang tudung yang licin, agak berminyak saat kondisi agak basah, dan memiliki tepi yang beralur. Diameter tudung jamur tiram mencapai $3-20 \mathrm{~cm}$ (Wiardani, 2010). Jamur tiram merupakan jamur kayu yang tumbuhnya berjejer pada kayu- 
kayuan yang sudah lapuk. Jamur tiram terdiri dari beberapa jenis yaitu jamur tiram pink muda, jamur tiram putih susu, jamur tiram coklat dan jamur tiram kelabu (Sumarmi, 2006).

Jamur tiram putih merupakan satu diantara jamur yang biasa dikenali dan banyak dikonsumsi oleh masyarakat, dikarenakan memiliki kandungan gizi yang sangat lengkap. Dalam 100 gram jamur tiram memiliki kandungan 367 kalori, 56,6\% karbohidrat, 10,5-30,4\% protein, 1,7-2,2\% lemak, 0,2 mg thianin, 4,7-4,9 mg riboflavin, $314 \mathrm{mg}$ kalsium (Ca) dan 77,2 mg niasin. Kandungan mineral penting didalam jamur tiram antara lain zat besi (Fe), fosfor (P), kalium (K) dan natrium (Na) (Asegab, 2011). Selain itu, jamur tiram putih mengandung manfaat bagi kebugaran tubuh diantaranya dapat menurunkan kolesterol darah, menghentikan pendarahan dan mempercepat pengeringan luka, penyempitan pembuluh darah, mencegah penyakit diabetes mellitus, mencegah penyakit kelenjar gondok, tumor atau kanker, influenza, serta memperlancar pembuangaan air besar, menambah vitalitas dan daya tahan tubuh (Djariyah dan Djariyah, 2001).

Berdasarkan data pusat statistika Indonesia pada tahun 2015, produksi jamur tiram putih di Indonesia terus mengalami penurunan pada tahun 2010 - 2014 mencapai 45\% (BPS, 2015). Oleh karena itu perbaikan dalam proses budidaya khususnya pemberian nutrisi dan zat pengatur tumbuh (ZPT) dari luar merupakan satu diantara cara yang ampuh dalam menambah produksi jamur di Indonesia. Vitamin dan zat pengatur tumbuh yang diberikan seharusnya aman untuk dikonsumsi oleh masyarakat. Perihal ini seiring dengan rencana pemerintah tentang pertanian organik.

Salah satu nutrisi dan zat pengatur tumbuh yang aman untuk dikunsumsi dan mudah didapatkan dikalangan masyarakat adalah air kelapa. Air kelapa memiliki kandungan gula dan mikro mineral yang berfungsi sebagai sumber nutrisi untuk jamur. Air kelapa memiliki kandungan asam organik dan asam amino serta mengandung gula (1,7-2,6 \%) yang bermanfaat untuk pertumbuhan tanaman (Young et al., 2009).

Perbedaan tingkat kemasakan buah secara langsung mempengaruhi komposisi nutrisi dari air kelapa. Air kelapa muda hijau lebih banyak mengandung kalium dan natrium dibandingkan air kelapa muda kuning (Khoeriyah, 2015). Oleh karena itu media tanam jamur tiram putih dalam penelitian, penyiramannya menggunakan air kelapa muda hijau.

Apabila diaplikasikan air kelapa muda pada tanaman akan memberikan pengaruh yang baik pada tanaman. Air kelapa muda mengandung protein, kalori, mineral dan sitokinin yang berfungsi untuk merangsang pertumbuhan mata tunas yang masih tidur pada beberapa tumbuhan tertentu. Kandungan dalam air kelapa yaitu seperti giberelin, auksin $0,07 \mathrm{mg}^{-1}$ dan sitokinin 5,8 $\mathrm{mg} \mathrm{l}^{-1}$ yang berfungsi untuk mendorong pertumbuhan dan perkecambahan suatu tanaman. Pengaplikasian air kelapa pada tanaman jamur tiram dapat membantu meningkatkan pertumbuhan dan hasil jamur tiram (Suhadirman, 1992).

Armawi (2009) menyebutkan bahwa hormon yang terkandung dalam air kelapa muda lebih banyak dibandingkan dengan air kelapa yang sudah tua yang berfungsi untuk pertumbuhan tanaman, hal ini disebabkan oleh bagian tanaman yang muda akan lebih aktif membelah dan membutuhkan hormon yang lebih besar. Hormon auksin yang aktif yang dihasilkan dalam jaringan meristematik yaitu tunas, daun muda dan buah (Gardner, 1991).

Hasil penelitian Hayati (2011) menunjukkan bahwa, zat pengatur tumbuh tanman yang terkandung pada air kelapa dapat meningginkan pertumbuhan dan hasil jamur merang pada konsentrasi 50\% dengan panjang tubuh buah yaitu 3,454 cm, diameter yaitu 3,321 dan jumlah total tubuh buah yaitu 136 buah. Sedangkan untuk perlakuan kontrol dengan panjang tubuh buah $2,978 \mathrm{~cm}$, diameter $2,851 \mathrm{~cm}$, dan jumlah total tubuh buah 73 buah. Sementara pada penelitian Agustina (2016) menunjukkan bahwa pemberian air kelapa muda dapat meningkatkan jumlah tubuh buah, berat basah, diameter tudung dan tinggi tangkai jamur tiram putih, perlakuan yang terbaik adalah pada pemberian $500 \mathrm{ml}$ air kelapa muda. 
Hasil penelitian khoeryah (2015) menunjukkan bahwa perlakuan yang memberikan pengaruh terbaik terhadap pertumbuhan jamur tiram putih(Pleurotus ostreatus) tedapat pada interval penyiraman media tanam jamur setiap dua hari sekali dengan berat rata-rata yaitu 123,6 g dan 89,6 g untuk perlakuan kontrol.

Pada penelitian Kurniawati (2005) menjelaskan bahwa penggunaan air kelapa dilakukan dengan cara disemprotkan, maka hasilnya akan lebih baik. Perihal ini disebabkan karena air kelapa memiliki kandungan seperti zat pengatur tumbuh yang bisa langsung diserap oleh hifa pada jamur.

Berdasarkan permasalahan diatas maka perlu dilakukan penelitian tentang pengaruh konsentrasi dan interval penyiraman air kelapa terhadap pertumbuhan dan hasil jamur tiram putih.

\section{METODOLOGI PENELITIAN}

\section{Tempat dan Waktu}

Penelitan ini dilaksanakan di UPTD Balai Benih Hortikultura Saree Kabupaten Aceh Besar, pada bulan Mei sampai Juli 2018.

\section{Alat dan Bahan}

Alat yang digunakan adalah ayakan, skop, timbangan, terpal warna hitam, timba, plastik polypropilen (pp) $18 \times 30$ ketebalan $0.6 \mathrm{~mm}$, cincin, karet gelang, drum bekas, tabung gas, kompor gas, terpal, karet ban, kayu, gelas, sendok, alkohol 70\%, spirtus, lampu spirtus (lampu bunsen), karet gelang, korek, kapas, potongan kertas, rak dan hand sprayer.

Bahan yang digunakan adalah bibit jamur tiram hasil koleksi UPTD BBH Saree dalam bentuk F2, serbuk kayu sebanyak 260 g, dedak 50 g, tepung jagung 10 g, kapur dolomit $10 \mathrm{~g}$, gipsum $10 \mathrm{~g}$, air sebanyak $600 \mathrm{ml}$ dan air kelapa sebanyak 36 liter.

\section{Rancangan Penelitian}

Penelitian ini menggunakan rancangan acak lengkap (RAL) pola faktorial dengan 2 faktor dan 3 ulangan. Faktor pertama yang diteliti adalah konsentrasi air kelapa yang terdiri atas 4 taraf yaitu 0, 25, 50, dan 75\% air kelapa. Faktor kedua adalah interval penyiraman air kelapa yang terdiri atas 4 taraf yaitu penyiraman setiap hari, penyiraman setiap 2 hari, penyiraman setiap 3 hari dan penyiraman setiap 4 hari sekali. Sehingga terdapat 48 unit percobaan, setiap satuan percobaan ada 3 baglog sehingga terdapat 144 baglog.

\section{Pelaksanaan Penelitian}

\subsubsection{Persiapan Kumbung}

Kumbung merupakan rumah budidaya jamur tiram. Kumbung yang akan digunakan dalam penelitian ini adalah kumbung yang terbuat dari kayu beratapakan genteng dan lantai yang terbuat dari semen (kumbung sudah tersedia). Didalam kumbung terdapat 4 ruang, yaitu ruang pembuatan media (ruang pengadukan), ruang pembibitan, ruang inkubasi dan ruang pemeliharaan. Sebelum melakukan penelitian, kumbung tersebut terlebih dahulu dibersihkan.

\subsubsection{Perlakuan Konsentrasi Air Kelapa}

Air kelapa diambil dari buah kelapa muda(memiliki tekstur daging yang lembut dan daging yang transparan), kemudian dikumpulkan ke wadah lalu disaring. Air kelapa tersebut diencerkan dengan cara mencampurkannya dengan air mineral sesuai dengan konsentrasi yang telah ditetapkan yaitu $0,25,50$ dan $75 \%$.

\subsubsection{Pembuatan Media Tanam/Baglog}

Media tanam yang digunakan adalah campuran serbuk kayu, dedak, kapur dolomit, tepung jagung, gipsun dan air secukupnya yang diaduk hingga merata. Kemudian 
ditambahkan air kelapa dengan konsentrasi yang telah ditetapkan. Selanjutnya campuran tersebut diperam(fermentasi) selama kurang lebih 1 hari. Kemudian dimasukkan ke dalam plastik hingga padat, diberi cincin dan diikat dengan karet.

\subsubsection{Sterilisasi}

Sterilisasi menggunakan drum dengan ukuran 200 liter yang telah diisi air sebanyak $3 / 4$ bagian, sterilisasi yang dilakukan yaitu dengan cara media jamur (baglog) dimasukkan ke dalam drum sterilisasi dan disusun hingga rapi. Kemudian ditutup bagian atas drum menggunakan terpal dan dikukus selama kurang lebih 2 jam agar media steril dengan merata.

\subsubsection{Pembibitan}

Media jamur (baglog) yang sudah dingin dapat dimasukkan ke ruang inokulasi dan didiamkan selama 1 hari. Selanjutnya dilakukan pembibitan dengan cara bagian penutup media baglog dibuka dan miselium yang ada pada bibit F2 diambil sebanyak 2 sendok teh dan dimasukkan ke dalam media baglog yang sudah steril. Kemudian ditutup menggunakan kertas dan diikat kembali menggunakan karet gelang. Selanjutnya dipindahkan ke ruang inkubasi hingga ditumbuhi miselium 100\%. Jika miselium pada baglognya sudah penuh akan dipindahkan ke ruang pemeliharaan.

\subsubsection{Pemeliharaan}

Pemeliharaan jamur tiram putih dapat dilakukan dengan cara pengabutan dan penyiraman. Pengabutan dilakukan dengan menggunakan sprayer yang telah diisi dengan air kemudian disemprotkan keseluruh ruangan yang akan digunakan untuk pertumbuhan jamur, pengabutan bisa dilakukan pada jam 10.00-12.00. Penyiraman dilakukan pada saat kertas pada media jamur dilepaskan. Pelepasan kertas pada media jamur dapat dilakukan ketika media jamur sudah terlihat miseliumnya dan terdapat tanda-tanda pinhead akan tumbuh, penyiraman dapat dilakukan mulai jam 9.00-15.00.

\subsubsection{Perlakuan Penyiraman}

Penyiraman dilakukan dengan cara menyemprotkan air ke media jamur yang sudah ditumbuhi miselium 100\% dengan menggunakan hand sprayer. Penyemprotan air kelapa sebanyak $1 \mathrm{ml}$ setiap baglognya sesuai dengan perlakuan inteval penyiraman. Penyemprotan dengan air dan air kelapa dilakukan bersamaan, yaitu setelah disemprot dengan air kelapa selanjutnya disemprot lagi baglog dengan menggunakan air mineral sampai kapasitas jenuh.

\subsubsection{Panen}

Jamur yang telah siap untuk panen berkisar 50 hari setelah inokulasi. Panen dapat dilakukan dengan cara mencabut jamur hingga ke pangkal tangkai buah, agar tidak menjadi kering dan mengahalangi tumbuhnya pinhead berikutnya. Panen dapat dilakukan dengan cara mencabutnya menggunakan tangan atau menggunakan pisau. Jamur tiram putih dapat dipanen sebanyak 6 kali.

\subsubsection{Parameter Pengamatan}

Parameter yang diamati adalah pertumbuhan awal miselium, laju pertumbuhan miselium, jumlah tubuh buah per rumpun, diameter tudung jamur, panjang tangkai tubuh buah, bobot segar tubuh buah selama 3 kali panen dan bobot segar tubuh buah per baglog. 


\section{HASIL DAN PEMBAHASAN}

\section{Hasil Penelitian \\ Rekapitulasi Hasil Analisis Ragam (Uji F) Pengaruh Konsentrasi dan Interval Penyiraman Air Kelapa terhadap Pertumbuhan dan Hasil Jamur Tiram Putih}

Hasil analisis ragam (Uji F) menunjukkan pengaruh konsentrasi dan interval penyiraman yang berbeda serta interaksi keduanya terhadap berbagai tolok ukur purtumbuhan dan hasil pada jamur tiram dapat dilihat pada tabel 1.

Pada Tabel 1 menunjukkan bahwa perlakuan konsentrasi air kelapa (K) pada media tanam jamur tiram putih berpengaruh sangat nyata terhadap parameter pertumbuhan awal miselium, diameter tudung jamur, jumlah tubuh buah, bobot segar tubuh buah per baglog, dan bobot segar tubuh buah selama 3 kali panen, namun berpengaruh tidak nyata terhadap parameter laju pertumbuhan miselium dan panjang tangkai tubuh buah.

Pada perlakuan interval penyiraman (I) berpengaruh sangat nyata terhadap parameter diameter tudung jamur, bobot segar tubuh buah per baglog, bobot segar tubuh buah selama 3 kali panen dan berpengaruh nyata pada parameter panjang tangkai tubuh, namun berpengaruh tidak nyata pada parameter pertumbuhan awal miselium, laju pertumbuhan miselium dan jumlah tubuh buah. Sedangkan untuk kombinasi perlakuan konsentrasi dan interval penyiraman yang berpengaruh nyata terdapat pada parameter diameter tudung jamur, namun tidak berpengaruh nyata pada parameter lainnya.

Tabel 1. Rekapitulasi Hasil Analisis Ragam (Uji F) Pengaruh Konsentrasi dan Interval Penyiraman terhadap Pertumbuhan dan Hasil Jamur Tiram Putih

\begin{tabular}{|c|c|c|c|c|}
\hline \multirow{2}{*}{ Parameter } & \multicolumn{3}{|c|}{ Perlakuan } & \multirow{2}{*}{ KK } \\
\hline & $\mathrm{K}$ & I & KxI & \\
\hline \multicolumn{5}{|l|}{ Pertumbuhan awal miselium (hari) } \\
\hline & $* *$ & tn & tn & 2,11 \\
\hline $\begin{array}{l}\text { Laju pertumbuhan miselium } \\
(\mathrm{cm} / \mathrm{hari})\end{array}$ & tn & tn & tn & 1,82 \\
\hline Panjang tangkai tubuh buah $(\mathrm{cm})$ & tn & $*$ & th & 3,14 \\
\hline Diameter tudung jamur (mm) & $* *$ & $* *$ & & 4,85 \\
\hline Jumlah tubuh buah (buah) & $* *$ & tn & $\operatorname{tn}$ & 7,56 \\
\hline $\begin{array}{l}\text { Bobot segar tubuh buah per baglog } \\
\text { (g) }\end{array}$ & $* *$ & $* *$ & $\operatorname{tn}$ & 6,52 \\
\hline Bobot segar selama 3 kali panen (g) & $* *$ & $* *$ & tn & 17,49 \\
\hline
\end{tabular}

\section{Pengaruh Konsentrasi Air Kelapa terhadap Pertumbuhan dan Hasil Jamur Tiram Putih}

Hasil analisis ragam (Uji F) menunjukkan bahwa perlakuan konsentrasi air kelapa berpengaruh sangat nyata terhadap parameter pertumbuhan awal miselium. diameter tudung 
jamur, jumlah tubuh buah, bobot segar tubuh buah per baglog dan bobot segar tubuh buah selama 3 kali panen, namun tidak berpengaruh nyata pada laju pertumbuhan miselium dan panjang tangkai tudung buah. Rata-rata nilai pertumbuhan jamur tiram dengan konsentrasi yang berbeda dapat dilihat pada tabel 2 .

Tabel 2. Rata-Rata Nilai Pertumbuhan Awal Miselium, Laju Pertumbuhan Miselium, Panjang Tangkai Tubuh Buah, Diameter Tudung Jamur, Jumlah Tubuh Buah, Bobot Segar Tubuh Buah Per Baglog dan Bobot Segar Tubuh Buah Selama 3 Kali Panen pada konsentrasi yang berbeda

\begin{tabular}{|c|c|c|c|c|c|}
\hline \multirow[t]{2}{*}{ Parameter } & \multicolumn{4}{|c|}{ Perlakuan Konsentrasi Air Kelapa (K) } & \multirow[b]{2}{*}{$\begin{array}{l}\mathrm{BNJ} \\
0,05\end{array}$} \\
\hline & $\begin{array}{l}0 \% \\
\left(\mathrm{~K}_{0}\right)\end{array}$ & $\begin{array}{l}25 \% \\
\left(\mathrm{~K}_{1}\right)\end{array}$ & $\begin{array}{l}50 \% \\
\left(\mathrm{~K}_{2}\right)\end{array}$ & $\begin{array}{l}75 \% \\
\left(\mathrm{~K}_{3}\right)\end{array}$ & \\
\hline $\begin{array}{l}\text { Pertumbuhan awal } \\
\text { miselium (hari) }\end{array}$ & $6,00 \mathrm{~b}$ & $6,00 \mathrm{~b}$ & 5,00 a & $7,00 \mathrm{c}$ & 0,53 \\
\hline $\begin{array}{l}\text { Laju pertumbuhan } \\
\text { miselium (cm/hari) }\end{array}$ & 0,39 & 0,34 & 0,39 & 0,32 & - \\
\hline $\begin{array}{l}\text { Panjang tangkai tubuh } \\
\text { buah }(\mathrm{cm})\end{array}$ & 5,67 & 5,91 & 6,42 & 5,96 & - \\
\hline $\begin{array}{l}\text { Diameter tudung jamur } \\
(\mathrm{mm})\end{array}$ & $77,88 \mathrm{a}$ & $81,89 \mathrm{ab}$ & $86,19 \mathrm{bc}$ & $86,24 \mathrm{c}$ & 4,33 \\
\hline Jumlah tubuh buah (buah) & $11,00 \mathrm{a}$ & $13,00 \mathrm{a}$ & $18,00 \mathrm{~b}$ & $13,00 \mathrm{a}$ & 3,07 \\
\hline $\begin{array}{l}\text { Bobot segar tubuh buah } \\
\text { per baglog }(\mathrm{g})\end{array}$ & $74,61 \mathrm{a}$ & $77,55 \mathrm{a}$ & 90,37 b & $77,80 \mathrm{a}$ & 4,87 \\
\hline $\begin{array}{l}\text { Bobot segar selama } 3 \text { kali } \\
\text { panen }(\mathrm{g})\end{array}$ & $198,24 \mathrm{a}$ & $237,97 \mathrm{~b}$ & 309,75 c & $229,87 \mathrm{~b}$ & 29,41 \\
\hline
\end{tabular}

Tabel 2 menunjukan rata-rata awal pertumbuhan miselium tertinggi terdapat pada perlakuan konsentrasi air kelapa $75 \%\left(\mathrm{~K}_{3}\right)$ yang berbeda nyata dengan perlakuan konsentrasi air kelapa $50 \%\left(\mathrm{~K}_{2}\right)$, konsentrasi air kelapa $25 \%\left(\mathrm{~K}_{1}\right)$, dan konsentrasi air kelapa 0\% atau kontrol $\left(\mathrm{K}_{0}\right)$. Awal pertumbuhan miselium terendah terdapat pada perlakuan konsentrasi air kelapa $50 \%\left(\mathrm{~K}_{2}\right)$.

Pada laju pertumbuhan miselium konsentrasi air kelapa $0 \%$ atau kontrol $\left(\mathrm{K}_{0}\right)$ dan konsentrasi air kelapa 50\% $\left(\mathrm{K}_{2}\right)$ cenderung lebih baik dibandingkan dengan konsentrasi air kelapa $25 \%\left(\mathrm{~K}_{1}\right)$ dan konsentrasi air kelapa $75 \%\left(\mathrm{~K}_{3}\right)$ meskipun secara statistik berpengaruh tidak nyata. Pada panjang tangkai tubuh buah konsentrasi air kelapa 50\% $\left(\mathrm{K}_{2}\right)$ cenderung lebih baik dibandingkan dengan yang lainnya meskipun secara statistik berpengaruh tidak nyata.

Rata-rata diameter tudung jamur tertinggi terdapat pada perlakuan konsentrasi air kelapa $75 \%\left(\mathrm{~K}_{3}\right)$ yang berbeda nyata dengan perlakuan kontrol $\left(\mathrm{K}_{0}\right)$ dan konsentrasi air kelapa $25 \%\left(\mathrm{~K}_{1}\right)$, namun tidak berbeda nyata dengan perlakuan konsentrasi air kelapa $50 \%\left(\mathrm{~K}_{2}\right)$. Diameter tudung jamur terendah terdapat pada perlakuan kontrol $\left(\mathrm{K}_{0}\right)$. Rata-rata jumlah tubuh buah tertinggi terdapat pada perlakuan konsentrasi air kelapa $50 \%\left(\mathrm{~K}_{2}\right)$ yang berbeda nyata dengan perlakuan kontrol $\left(\mathrm{K}_{0}\right)$, konsentrasi air kelapa $25 \%\left(\mathrm{~K}_{1}\right)$, dan konsentrasi air kelapa $75 \%\left(\mathrm{~K}_{3}\right)$. Jumlah tubuh buah terendah terdapat pada perlakuan kontrol $\left(\mathrm{K}_{0}\right)$.

Rata-rata bobot segar tubuh buah tertinggi terdapat pada perlakuan konsentrasi air kelapa $50 \%\left(\mathrm{~K}_{2}\right)$ yang berbeda nyata dengan perlakuan kontrol $\left(\mathrm{K}_{0}\right)$, konsentrasi air kelapa $25 \%\left(\mathrm{~K}_{1}\right)$, dan konsentrasi air kelapa $75 \%\left(\mathrm{~K}_{3}\right)$. Bobot segar tubuh buah terendah terdapat pada perlakuan konsentrasi air kelapa $0 \%$ atau kontrol $\left(\mathrm{K}_{0}\right)$. Rata-rata bobot segar tubuh buah 
selama 3 kali panen tertinggi terdapat pada perlakuan konsentrasi air kelapa $50 \%\left(\mathrm{~K}_{2}\right)$ yang berbeda nyata dengan perlakuan kontrol $\left(\mathrm{K}_{0}\right)$, konsentrasi air kelapa $25 \%\left(\mathrm{~K}_{1}\right)$, dan konsentrasi air kelapa $75 \%\left(\mathrm{~K}_{3}\right)$. bobot segar tubuh buah selama 3 kali panen terdapat pada perlakuan konsentrasi air kelapa $0 \%$ atau kontrol $\left(\mathrm{K}_{0}\right)$.

\section{Pengaruh Interval Penyiraman terhadap Pertumbuhan dan Hasil Jamur Tiram Putih}

Hasil analisis ragam (Uji F) menunjukkan bahwa interval penyiraman berpengaruh sangat nyata pada diameter tudung jamur, bobot segar tubuh buah perbaglog, bobot segar tubuh buah selama 3 kali panen dan berpengaruh nyata pada panjang tangkai tudung buah, namun berpengaruh tidak nyata pada pertumbuhan awal miselium, laju pertumbuhan miselium dan jumlah tubuh buah jamur. Rata-rata nilai pertumbuhan awal miselium, laju pertumbuhan miselium, panjang tangkai tubuh buah, diameter tudung jamur, jumlah tubuh buah, bobot segar tubuh buah per baglog dan bobot segar tubuh buah selama 3 kali panen pada interval penyiraman yang berbeda dapat dilihat pada Tabel 3.

Tabel 3. Rata-Rata Nilai Pertumbuhan Awal Miselium, Laju Pertumbuhan Miselium, Panjang Tangkai Tubuh Buah, Diameter Tudung Jamur, Jumlah Tubuh Buah, Bobot Segar Tubuh Buah Per Baglog dan Bobot Segar Tubuh Buah Selama 3 Kali Panen pada interval penyiraman yang berbeda

\begin{tabular}{|c|c|c|c|c|c|}
\hline \multirow[b]{2}{*}{ Parameter } & \multicolumn{4}{|c|}{ Perlakuan Interval Penyiraman (I) } & \multirow[b]{2}{*}{ BNJ 0,05} \\
\hline & $\begin{array}{c}1 \text { hari sekali } \\
\left(\mathrm{I}_{1}\right)\end{array}$ & $\begin{array}{l}2 \text { hari sekali } \\
\qquad\left(\mathrm{I}_{2}\right)\end{array}$ & $\begin{array}{c}3 \text { hari sekali } \\
\left(\mathrm{I}_{3}\right)\end{array}$ & $\begin{array}{l}4 \text { hari sekali } \\
\left(\mathrm{I}_{4}\right)\end{array}$ & \\
\hline $\begin{array}{l}\text { Pertumbuhan awal } \\
\text { miselium (hari) }\end{array}$ & 6,00 & 6,00 & 6,00 & 6,00 & - \\
\hline $\begin{array}{l}\text { Laju pertumbuhan } \\
\text { miselium }(\mathrm{cm} / \text { hari })\end{array}$ & 0,37 & 0,34 & 0,37 & 0,36 & - \\
\hline $\begin{array}{l}\text { Panjang tangkai } \\
\text { tubuh buah }(\mathrm{cm})\end{array}$ & $6,15 \mathrm{ab}$ & 6,50 b & $5,88 \mathrm{a}$ & $5,43 \mathrm{a}$ & 0,76 \\
\hline $\begin{array}{l}\text { Diameter tudung } \\
\text { jamur }(\mathrm{mm})\end{array}$ & $84,91 \mathrm{bc}$ & $86,33 \mathrm{c}$ & $81,25 \mathrm{ab}$ & 79,71 a & 4,33 \\
\hline $\begin{array}{l}\text { Jumlah tubuh buah } \\
\text { (buah) }\end{array}$ & 14,00 & 13,00 & 13,00 & 14,00 & - \\
\hline $\begin{array}{l}\text { Bobot segar tubuh } \\
\text { buah per baglog }(\mathrm{g})\end{array}$ & $81,11 \mathrm{ab}$ & 85,72 b & 77,08 a & 77,12 a & 4,87 \\
\hline $\begin{array}{l}\text { Bobot segar selama } \\
3 \text { kali panen }(\mathrm{g})\end{array}$ & $250,91 \mathrm{~b}$ & 288,09 c & $219,28 \mathrm{a}$ & $222,61 \mathrm{ab}$ & 29,41 \\
\hline
\end{tabular}

Tabel 3 menunjukkan bahwa semua perlakuan interval penyiraman pada parameter pertumbuhan awal miselium menunjukkan hasil yang sama yaitu hari ke-6. Laju pertumbuhan miselium menunjukkan nilai cenderung terbaik terdapat pada perlakuan interval penyiraman 1 hari sekali $\left(\mathrm{I}_{1}\right)$ dan 3 hari sekali $\left(\mathrm{I}_{3}\right)$ dibandingkan dengan perlakuan interval penyiraman 2 hari sekali $\left(\mathrm{I}_{2}\right)$ dan 4 hari sekali $\left(\mathrm{I}_{4}\right)$ meskipun secara statistik berpengaruh tidak nyata.

Rata-rata panjang tangkai tudung buah tertinggi terdapat pada perlakuan interval penyiraman 2 hari sekali $\left(I_{2}\right)$ yang berbeda nyata dengan perlakuan interval penyiraman 3 hari sekali $\left(\mathrm{I}_{3}\right)$ dan interval penyiraman 4 hari sekali $\left(\mathrm{I}_{4}\right)$, namun tidak berbeda nyata dengan perlakuan interval penyiraman sehari sekali $\left(\mathrm{I}_{1}\right)$. Rata-rata diameter tudung jamur cenderung lebih baik terdapat pada perlakuan interval penyiraman 2 kali sehari $\left(I_{2}\right)$ yang berbeda nyata 
dengan perlakuan interval penyiraman 3 kali sehari $\left(I_{3}\right)$ dan interval penyiraman 4 kali sehari $\left(\mathrm{I}_{4}\right)$, namun tidak berbeda nyata dengan perlakuan interval penyiraman sehari sekali $\left(\mathrm{I}_{1}\right)$.

Jumlah tubuh buah terbaik terdapat pada perlakuan interval penyiraman 1 hari sekali $\left(\mathrm{I}_{1}\right)$ dan 4 hari sekali $\left(\mathrm{I}_{4}\right)$ dibandingkan perlakuan interval penyiraman 2 hari sekali $\left(\mathrm{I}_{2}\right)$ dan 3 hari sekali $\left(\mathrm{I}_{3}\right)$ meskipun secara statistik berpengaruh tidak nyata. Rata-rata bobot segar tubuh buah tertinggi terdapat pada perlakuan interval penyiraman 32 hari sekali $\left(I_{2}\right)$ yang berbeda nyata dengan perlakuan interval penyiraman 3 hari sekali $\left(I_{3}\right)$ dan interval penyiraman 4 hari sekali $\left(\mathrm{I}_{4}\right)$, namun tidak berbeda nyata dengan perlakuan interval penyiraman sehari sekalli $\left(\mathrm{I}_{1}\right)$. Rata-rata bobot segar selama 3 kali panen tertinggi terdapat pada perlakuan interval penyiraman 2 hari sekali $\left(\mathrm{I}_{2}\right)$ yang berbeda nyata dengan perlakuan interval penyiraman sehari sekali $\left(\mathrm{I}_{1}\right)$, interval penyiraman 3 hari sekali $\left(\mathrm{I}_{3}\right)$ dan interval pentiraman 4 hari sekali $\left(\mathrm{I}_{4}\right)$.

\section{Pengaruh Interaksi antara Konsentrasi dan Interval Penyiraman Air Kelapa terhadap Pertumbuhan dan Hasil Jamur Tiram Putih}

Hasil analisis ragam (Uji F) pada lampiran menunjukkan bahwa terdapat interaksi yang nyata antara perlakuan konsentrasi air kelapa dan interval penyiraman terhadap diameter tudung jamur. Rata-rata interaksi diameter tudung jamur dapat dilihat pada Tabel 4.

Tabel 4. Rata-Rata Diameter Tudung Jamur (mm) pada berbagai Kombinasi Perlakuan Konsentrasi dan Interval Penyiraman Air Kelapa

\begin{tabular}{ccccc}
\hline \multirow{2}{*}{$\begin{array}{c}\text { Konsentrasi Air Kelapa } \\
(\mathrm{K})\end{array}$} & \begin{tabular}{c} 
Interval penyiraman $(\mathrm{I})$ \\
\cline { 2 - 5 }$\left(\mathrm{I}_{1}\right)$
\end{tabular} & $\begin{array}{c}\text { hari sekali sekali } \\
\left(\mathrm{I}_{2}\right)\end{array}$ & $\begin{array}{c}3 \text { hari sekali } \\
\left(\mathrm{I}_{3}\right)\end{array}$ & $\begin{array}{c}4 \text { hari sekali } \\
\left(\mathrm{I}_{4}\right)\end{array}$ \\
\hline $0 \%\left(\mathrm{~K}_{0}\right)$ & $79,91 \mathrm{ab}$ & $77,46 \mathrm{a}$ & $76,86 \mathrm{a}$ & $77,28 \mathrm{a}$ \\
$25 \%\left(\mathrm{~K}_{1}\right)$ & $84,71 \mathrm{bcd}$ & $85,52 \mathrm{bcd}$ & $75,84 \mathrm{a}$ & $81,51 \mathrm{abc}$ \\
$50 \%\left(\mathrm{~K}_{2}\right)$ & $89,00 \mathrm{de}$ & $93,00 \mathrm{e}$ & $83,62 \mathrm{bcd}$ & $79,15 \mathrm{ab}$ \\
$75 \%\left(\mathrm{~K}_{3}\right)$ & $86,02 \mathrm{~cd}$ & $89,34 \mathrm{de}$ & $88,69 \mathrm{de}$ & $80,91 \mathrm{abc}$ \\
\hline
\end{tabular}

BNJ 5,95
$\begin{gathered}\text { Keterangan : } \\ \text { pangka yang diikuti oleh huruf yang sama pada kolom dan baris yang sama berbeda tidak nyata } \\ \text { paji BNJ) }\end{gathered}$

Tabel 4 menunjukkan nilai kombinasi perlakuan konsentrasi air kelapa dan interval penyiraman terhadap diameter tudung jamur terbaik terdapat pada perlakuan konsentrasi $50 \%$ dengan interval penyiraman 2 hari sekali $\left(\mathrm{K}_{2} \mathrm{I}_{2}\right)$ yang berbeda tidak nyata dengan perlakuan konsentrasi air kelapa 50\% dengan interval penyiraman 1 hari sekali $\left(\mathrm{K}_{2} \mathrm{I}_{1}\right)$, konsentrasi air kelapa $75 \%$ dengan interval penyiraman 2 hari sekali $\left(\mathrm{K}_{3} \mathrm{I}_{2}\right)$ dan konsentrasi air kelapa $75 \%$ dengan interval penyiraman 3 hari sekali $\left(\mathrm{K}_{3} \mathrm{I}_{3}\right)$, namun berbeda nyata dengan kombinasi perlakuan lainnya.

\section{Pembahasan}

\section{Pengaruh Konsentrasi Air Kelapa terhadap Pertumbuhan dan Hasil Jamur Tiram Putih}

Berdasarkan hasil penelitian pada parameter awal pertumbuhan miselium, jumlah tubuh buah jamur, bobot segar perbaglog, dan bobot segar selama 3 kali panen menunjukkan nilai tertinggi terdapat pada perlakuan konsentrasi air kelapa 50\%, sedangkan untuk perlakuan yang mendapatkan nilai terendah adalah pada perlakuan konsentrasi 0\%,. Faktor tinggi 
rendahnya konsentrasi berhubungan erat dengan kandungan yang terdapat dalam air kelapa tersebut. Air kelapa diduga memiliki kandungan nutrisi dan zat pengatur tumbuh yang dibutuhkan oleh tanaman sehingga mampu meningkatkan pertumbuhan tanaman. Jumlah yang diaplikasikan ke tanaman harus sesuai dengan yang dibutuhkan oleh tanaman tersebut. Konsentrasi air kelapa $50 \%$ merupakan konsentrasi yang tepat untuk diaplikasikan pada media jamur tiram dibandingkan dengan konsentrasi 25 dan 75\%.Konsentrasi $25 \%$ diduga mengandung nutrisi dan zat pengatur tumbuh yang sedikit sehingga pertumbuhan jamur menjadi terhambat. Berdasarkan hasil penelitian Untari dan Dwi (2006) menyatakan bahwa air kelapa mengandung zat/bahan-bahan seperti unsur hara, vitamin, asam amino, asam nukleat dan zat tumbuh seperti auksin dan giberelin yang berfungsi sebagai penstimulasi poliferasi jaringan, memperlancar metabolisme dan respirasi yang apabila diaplikasikan secara tepat bagi tanaman.

Hal ini sesuai dengan penelitian Hayati (2011), yang menyatakan bahwa jamur membutuhkan bahan tambahan untuk pertumbuhannya yang bertujuan untuk mengaktifkan mikroflora yang akan merombak sellulosa, hemiselulosa serta lignin maka nutrisi yang tersedia akan lebih mudah dicerna oleh jamur dan hasil dari pengomposan mendapatkan zat asam amino, protein, $\mathrm{CO}_{2}, \mathrm{H}_{2} \mathrm{O}$, dan $\mathrm{NH}_{3}$. Hasil $\mathrm{NH}_{3}$ yang berlebihan dalam medium akan menghambat pertumbuhan miselium. Penimbunan $\mathrm{CO}_{2}$ yang berlebihan akan menyebabkan salah bentuk pada tubuh buah, tangkai sangat panjang, bahkan sampai tidak terbentuk tubuh buah. Kandungan dalam air kelapa yaitu zat pengatur tumbuh organik terutama IAA (Auksin, Giberelin, dan sitokinin) yang dapat merangsang dan mempercepat pertumbuhan jamur.

Agustina (2016) menyatakan bahwa pemberian air kelapa berpengaruh terhadap berat basah tubuh buah jamur, karena pada air kelapa memiliki kandungan hormon auksin dan sitokinin yang dapat mempengaruhi kualitas hasil panen salah satunya berat basah tubuh buah jamur. Auksin berfungsi membantu menaikkan kualitas produksi panen, merangsang proses terbentuknya akar serta pertumbuhan akar dengan baik, memacu dan menaikkan protease timbulnya tubuh buah.

Pada parameter diameter tudung jamur menunjukkan nilai tertinggi terdapat pada perlakuan konsentrasi air kelapa 75\%. Menurut Kurniawati (2005) air kelapa memberikan pengaruh terhadap panjang dan diameter tubuh buah jamur. Jamur mengambil zat organik dari lingkungannya melalui hifa dan miseliumnya untuk memperoleh makanan, semakin banyak air kelapa yang diberikan semakin besar lebar tudung jamur yang dihasilkan kemudian menyimpannya dalam bentuk glikogen.

\section{Pengaruh Interval Penyiraman Air Kelapa terhadap Pertumbuhan dan Hasil Jamur Tiram Putih}

Berdasarkan hasil penelitian perlakuan interval penyiraman selama tahap pemeliharaan menunjukkan pengaruh nyata pada parameter diameter tudung jamur, panjang tangkai tudung buah jamur, bobot segar tubuh buah dan bobot segar selama 3 kali panen. Pada saat penumbuhan tubuh buah jamur diperlukan adanya penyiraman disekeliling media tumbuh jamur. Penyiraman dilakukan dengan cara menyemprotkan dengan menggunakan hand sprayer yang menghasilkan butiran-butiran halus. Adapun tujuannya adalah untuk menurunkan suhu udara dan menaikkan kelembapan udara. Hasil penelitian menunjukkan bahwa perlakuan interval penyiraman 2 hari sekali $\left(\mathrm{I}_{2}\right)$ merupakan interval terbaik untuk penyiraman pada jamur, karena semua parameter yang menunjukkan pengaruh nyata memiliki nilai tertinggi pada perlakuan interval penyiraman 2 hari sekali $\left(\mathrm{I}_{2}\right)$. Sedangkan nilai terendah terdapat pada perlakuan interval penyiraman 3 hari sekali $\left(\mathrm{I}_{3}\right)$ dan 4 hari sekali $\left(\mathrm{I}_{4}\right)$. Hal ini diduga karena air kelapa mengandung hormon auksin dan sitokinin dan interval 2 hari sekali merupakan pemberian terbaik terhadap jamur tiram putih. Adapun pada perlakuan interval 
penyiraman air kelapa 1 hari sekali $\left(\mathrm{I}_{1}\right), 3$ hari sekali $\left(\mathrm{I}_{3}\right)$, dan 4 hari sekali $\left(\mathrm{I}_{4}\right)$ diduga fitohormon yang diberikan belum mampu mencapai batas konsentrasi yang diperlukan jamur tiram putih untuk pertumbuhan tubuh buahnya. Pada perlakuan interval penyiraman air kelapa 1 hari sekali $\left(\mathrm{I}_{1}\right)$ hormon yang diberikan pada jamur terlalu banyak sehingga mengakibatkan pertumbuhannya terhambat. Namun pada perlakuan interval penyiraman 3 hari sekali $\left(I_{3}\right)$ dan interval penyiraman 4 hari sekali $\left(\mathrm{I}_{4}\right)$ hormon yang terkandung didalamnya terlalu rendah karena interval pemberiannya yang lama. Hal ini sesuai dengan penelitian Khoeryah (2015) yang menyatakan bahwa air kelapa yang diberikan setiap 2 hari sekali mengandung fitohormon auksin dan sitokinin yang cukup, selain itu juga diduga karena zat-zat yang terkandung dalam air kelapa dapat diserap langsung oleh jamur.

Suriawiria (2001) menyatakan bahawa tanaman memiliki batas waktu tertentu dalam menerima unsur hara. pertumbuhan tanaman dapat terhambat apabila konsentrasi unsur hara yang diberikan kurang dari yang dibutuhkan oleh tanaman, hal tersebut disebabkan oleh proses metabolisme yang kekurangan unsur. pertumbuhan jamur juga mengalami gangguan apabila konsentrasi hormon yang diberikan terlalu tinggi, hal ini dapat menyebabkan perkembangan tubuh buah tidak baik. Pertumbuhan jamur tersebut terhambat karena terjadinya penimbunan hormon.

\section{Pengaruh Interaksi antara Konsentrasi dan Interval Penyiraman Air Kelapa terhadap Pertumbuhan dan Hasil Jamur Tiram Putih}

Kombinasi perlakuan antara konsentrasi air kelapa 50\% dengan interval penyiraman 2 hari sekali $\left(\mathrm{K}_{2} \mathrm{I}_{2}\right)$ menunjukkan pengaruh yang nyata terhadap parameter diameter tudung jamur. Hal ini diyakini bahwa interaksi perlakuan tersebut menunjukkan kemampuan lebih baik dalam meningkatkan pertumbuhan jamur tiram putih dibandingkan kombinasi perlakuan lainnya. Berdasarkan hasil penelitian, dapat dilihat bahwa jamur tiram putih yang memiliki pertumbuhan terbaik merupakan jamur yang diberikan konsentrasi air kelapa 50\%, disiram dengan interval penyiraman 2 hari sekali saling mempengaruhi dan bekerja sama dalam peningkatan pertumbuhan yang optimum.

Penelitian Kurniawati (2005) enyatakan bahwa air kelapa memberikan pengaruh terhadap diameter dan panjang tubuh buah pada jamur. jamur dapat memperoleh makanan dengan cara menyerap zat organik yang ada disekitar lingkungannya melalui hifa dan miseliumnya. konsentrasi dan interval penyiraman yang tepat dan diberikan dengan cara disemprot akan memperoleh hasil yang lebhi baik. Hal tersebut dikarenakan jamur dapat menyerap langsung zat pengatur tumbuh tersebut. Menurut Gunawan (2005) peningkatan diameter jamur dapat disebabkan karena adanya tambahan hormon yang diberikan sehingga dapat meningkatkan penyerapan hormon. Sebagai makhluk hidup, jamur mebutuhkan nutrisi untuk pertumbuhan dan perkembangannya. jamur dapat memperoleh nutrisi tersebut dari medianya secara langsung dalam bentuk unsur, ion dan karbon yang merupakan unsur dasar pembangun sel dan merupakan sumber energi yang diperlukan oleh jamur dan unsur nitrogen yang dibutuhkan dalam sintesis protein dan pertumbuhan jamur.

\section{SIMPULAN DAN SARAN}

\section{Simpulan}

Konsentrasi air kelapa berpengaruh sangat nyata terhadap pertumbuhan awal miselium, diameter tudung jamur, jumlah tubuh buah jamur, bobot segar perbaglog, dan bobot segar selama 3 kali panen, namun berpengaruh tidak nyata pada laju pertumbuhan miselium 
dan panjang tangkai tubuh buah. Pertumbuhan dan hasil jamur tiram terbaik terdapat pada perlakuan konsentrasi air kelapa 50\%.

Interval penyiraman air kelapa berpengaruh sangat nyata terhadap diameter tudung jamur, bobot segar tubuh buah/baglog dan bobot segar tubuh buah jamur selama 3 kali panen/baglog, berpengaruh nyata terhadap panjang tangkai tubuh buah, namun tidak berpengaruh nyata terhadap awal pertumbuhan miselium. Laju pertumbuhan miselium, dan jumlah tubuh buah. Pertumbuhan dan hasil jamur tiram putih terbaik terdapat pada perlakuan interval penyiraman 2 hari sekali.

Terdapat interaksi yang nyata antara perlakuan konsentrasi air kelapa dan interval penyiraman terhadap diameter tudung buah. Jamur tiram putih yang memiliki tudung terlebar terdapat pada perlakuan konsentrasi air kelapa 50\% dan interval penyiraman 2 hari sekali.

\section{Saran}

Sehubungan dengan penelitian ini perlu dilakukan penelitian lebih lanjut mengenai pemberian nutrisi dan hormon organik pada jamur tiram putih dengan konsentrasi dan interval penyiraman yang berbeda selain dengan pemberian air kelapa.

\section{DAFTAR PUSTAKA}

Agustina A. 2016. Efektifitas pemberian air kelapa muda (Cocos nucifera) terhadap pertumbuhan jamur tiram putih (Pleuorotus ostreatus). Skripsi. Jurusan Biologi Fakultas Matematika dan Ilmu Pengetahuan Alam Universitas Pakuan, Bogor.

Armawi. 2009. Pengaruh tingkat kemasakan buah kelapa dan konsentrasi air kelapa pada media tanam terhadap pertumbuhan jamur tiram putih (Pleurotus ostreatus). Skripsi. Jurusan Biologi Fakultas Sains dan Teknologi Universitas Islam Negeri (UIN) Maulana Malik Ibrahim Malang, Malang.

Bada Pusat Statistik (BPS). 2015. Statistik Indonesia 2015. http://www.bps.go.id/site/res ultTab. Diakses Tanggal 12 April 2017.

Djariyah, N.M., dan A.S Djariyah. 2001. Budi Daya Jamur Tiram: Pembibitan Pemeliharaan dan Pengendalian Hama Penyakit. Penerbit Kanisius, Yogyakarta.

Gardner, F.P. 1991. Fisiologi Tanaman Budidaya. UI Press, Jakarta.

Gunawan, A.W. 2000. Usaha Pembibitan Jamur. Penebar Swadaya, Jakarta.

Hayati A. 2011. Pengaruh frekuensi dan konsentrasi pemberian air kelapa terhadap pertumbuhan dan hasil jamur merang. Skripsi. Fakultas Pertanian Universitas Jember.

Khoeriyah, T. 2015. Pengaruh pemberian air kelapa (Cocos nucifera) pada media tanam terhadap pertumbuhan jamur tiram putih (Pleurotus ostreatus). Skripsi. Institut Islam Negeri Palangka Raya, Kalimantan Tengah. 
Kurniawati, D. T. 2005. Pengaruh penambahan IAA, air kelapa dan ekstrak taoge terhadap pertumbuhan dan hasil tiga jenis jamur tiram. Skripsi. Universitas Muhammadiyah Malang, Malang.

Suhadirman. P. 1992. Jamur Merang. Penebar Swadaya. Jakarta.

Sumarmi. 2006. Botani dan Tinjauan gizi jamur tiram putih. Jurnal Inovasi Pertanian. 4(2):124-130.

Suriawiria. 2001. Budidaya Jamur Shitake. Penebar swadaya, Jakarta.

Untari, R dan Dwi, M.P. 2006 . Pengaruh bahan organik dan NAA terhadap pertumbuhan anggrek hitam (Coelogyne pandurata Lindl) dalam kultur in vitro. Biodiversitas, Bogor. 7(3): 344-348.

Wiardani, I. 2010. Budidaya Jamur Konsumsi. ANDI, Yogyakarta.

Yong, J.W.H., L. Ge, Y.F. Ng dan S.N Tan. 2009. The chemical composition and biological properties of coconut (Cocos nucifera) water. Molecules, Singapore. 14: 5144-5164.

Yulianti. 2006. Pengaruh ph terhadap pertumbuhan jamur Colletotrichum capsici penyebab penyakit antraknosa pada cabai (Capsicum annum L.) asal Lampung. Skripsi. Fakultas Matematika dan Ilmu Pengetahuan Alam Universitas Semarang, Semarang.

Yusnida. 2000. Budidaya Jamur Merang. Yepentra Hagutani, Cianjur 